\title{
Genomic Instability and Cytotoxicity in Buccal Mucosal Cells of Workers in Banana Farming Evaluated by Micronucleus Test
}

\author{
SAMUEL RANGEL CLAUDIO ${ }^{1}$, JOSE MARTIM MARQUES SIMAS ${ }^{2}$, ANA CAROLINA FLYGARE SOUZA ${ }^{3}$, \\ MARIA DO CARMO BARACHO DE ALENCAR ${ }^{2}$, LIRIA YURI YAMAUCHI ${ }^{3}$ and DANIEL ARAKI RIBEIRO ${ }^{1}$ \\ ${ }^{1}$ Department of Biosciences, Federal University of Sao Paulo, UNIFESP, Santos, Brazil; \\ ${ }^{2}$ Department of Health, Education and Society, Federal University of Sao Paulo, UNIFESP, Santos, Brazil; \\ ${ }^{3}$ Department of Human Movement, Federal University of Sao Paulo, UNIFESP, Santos, Brazil
}

\begin{abstract}
Background/Aim: Studies have demonstrated the biological consequences of environmental contamination caused by human pesticide exposure following banana production. The aim of this study was to evaluate genomic instability and cytotoxicity in buccal mucosal cells of workers in banana farming. Materials and Methods: For this purpose, a total of 21 male workers in banana farming in the Ribeira Valley were included in the experimental group. A total of 20 individuals, not occupationally exposed to pesticides, were included in the control group. Results: The frequency of micronuclei was significantly increased $(p<0.05)$ in buccal mucosa cells from workers of banana farming when compared to the control group. Furthermore, a high frequency of karyolysis was detected in buccal mucosal cells in these individuals. No significant differences were found in pyknosis or karryorhexis when compared to controls. Conclusion: Taken together, our results indicate that workers in banana farming represent a group in high risk for carcinogenesis since chromosomal damage and cellular death are increased in these individuals.
\end{abstract}

The Ribeira Valley has environmental, social and cultural wealth due to the combination of its several ethnicities and environmental preservation. This region is the largest Brazilian Atlantic Forest preserved in the territory, with one of the biomes with the highest biodiversity in the world (1). In 1999, this region was declared a World Natural Heritage Site containing 190,000 hectares of restinga, 30,000 hectares of mangroves, 300 caves, archaeological sites and monuments,

Correspondence to: Daniel Araki Ribeiro, DDS, Ph.D., Departamento de Biociências, Universidade Federal de São Paulo - UNIFESP, R. Silva Jardim, 136, Room 332, Zip code: 11050-020, Santos - SP, Brazil. Tel/Fax: +55 1332290156, e-mail: daribeiro@unifesp.br

Key Words: Oral mucosaI cells, banana farming, micronucleus test, biomonitoring. besides water quality suitable for both human supply and aquatic fauna (1). It is important to stress that banana farming has a high importance in national agricultural production in this region, where Brazil is considered the largest consumer of banana in natura and the fourth largest producer of the fruit in the world (2). This corresponds to $7 \%$ of world production and Brazil is the largest banana exporter of Latin America, with more than two-thirds of the consignments of the fruit passed on to other countries (3).

It has been established that one of the great problems that affects human populations is continuous exposure to harmful chemicals released into the environment from anthropogenic activities (4). In Latin America, studies have demonstrated the biological consequences of environmental contamination caused by human pesticide exposure following banana production $(5,6)$. Pesticides are one of the main contaminants to which people are exposed (7). It is well documented that continuous exposure to pesticides impairs many biological functions and cellular systems. In fact, it has been documented that such exposure induces a myriad of harmful effects on human health (8-10). In particular, exposure to pesticides is closely associated with Parkinson's disease (11), Alzheimer's disease (12), diabetes (13), and cancer (14).

In this context, identifying what types of chemicals from natural or anthropogenic origins people are exposed to is mandatory for evaluating the real risks for human health (7). There are several assays available for detecting chemical substances present in pesticides; however, they remain very expensive and are time-consuming due to the wide range of formulations present in these pesticide products, many of which are, as yet, unknown (7). To overcome this, biomarkers are of great value for biomonitoring some populations in order to identify early biological effects in these exposed individuals (7). Certainly, the use of biomarkers is very useful for enabling prevention or mitigation of the dangerous effects by considering individual susceptibility. Among them, assay of micronuclei using buccal mucosal cells is fast, low cost, reproducible and non-invasive for evaluating cytogenetic damage (15). This 
methodology permits the detection of chromosomal damage induced by physical, chemical and biological sources. Furthermore, detection of meta-nuclear changes indicative of cytotoxicity, for example pyknosis, karyolysis and karyorrhexis, considerably improves the sensitivity of the assay (16).

Because of the lack of scientific evidence regarding the cytogenetic biomonitoring of workers in banana farming, the aim of this study was to investigate the mutagenicity and cytotoxicity in buccal mucosal cells by micronucleus assay.

\section{Materials and Methods}

The study area. The study area is located between coordinates $24^{\circ} 29^{\prime} 15^{\prime \prime} \mathrm{S}$ and $47^{\circ} 50^{\prime} 37^{\prime \prime} \mathrm{W}$, in the extreme southwestern zone of the Sao Paulo State, in the city of Registro, Brazil.

Participants. The subjects of this study comprised 21 men, with mean age $( \pm \mathrm{SD})$ of $38.2 \pm 13.8$ years. The following criteria were established for participating in the study: (i) having worked at least 1 year as worker in banana farming; (ii) working $40 \mathrm{~h}$ a week; (iii) no systemic disease such as hypertension, diabetes or cancer; (iv) not continuous use of drugs; (v) no oral lesion; (vi) to be not submitted to dental radiography in the last 15 days (vii) consent to participation in the study. The control group consisted of 20 healthy men matched by age to the experimental group (33.6 \pm 15.3 years), not occupationally exposed to any pesticides, following the same criteria adopted for selecting the individuals for the experimental group. In order to avoid potential confounding factors, none of the volunteers were smokers. The consumption of alcohol or use of mouth rinses was not recorded in this setting. The study was approved by the Ethics Committee of the Federal University of Sao Paulo, Brazil (protocol number 0361/2018). Informed consent was obtained from all individuals included in the study.

Micronucleus test on oral mucosal cells. Buccal mucosal cells were collected with a wooden spatula. The cellular suspension was transferred to a tube containing saline solution, which was then centrifuged $(850 \times g)$ for $5 \mathrm{~min}$, fixed in 3:1 methanol/acetic acid, and dropped onto pre-cleaned slides. The air-dried slides were stained using the Feulgen/Fast-Green method as described elsewhere (15).

The occurrence of micronucleated cells was assessed according to Belien et al. (15). For cytotoxicity, the following meta-nuclear changes were considered in this study: pyknosis, karyolysis and karyorrhexis. This analysis was based on a previous study conducted by our research group (17). A total of 2,000 cells were evaluated per volunteer.

Statistical methods. The Mann-Whitney non-parametric test was used to evaluate cytotoxicity. The presence of micronucleated cells was made as established by Pereira (18). The statistical analysis was conducted using BioStat software, version 5.0 (Maringa, PR, Brazil). The level of statistical significance was set at $p<0.05$.

\section{Results}

The results from this study showed an almost 10 -fold increase of micronucleated buccal mucosal cells of workers in banana farming when compared to the control group $(p<0.05)$. The results are demonstrated in Table I.
Table I. Micronucleus incidence (mean $\pm S D$ ) in buccal mucosal cells of workers in banana farming and controls.

\begin{tabular}{lc}
\hline Group & Micronucleus incidence \\
\hline Controls $(\mathrm{n}=20)$ & $0.1 \pm 0.2$ \\
Workers $(\mathrm{n}=21)$ & $0.95 \pm 1.5^{*}$ \\
\hline
\end{tabular}

*Significantly different at $p<0.05$ when compared to controls.

Table II. Cytotoxicity (mean $\pm S D$ ) as reflected in karyorrhexis, pyknosis and karyolysis in buccal mucosal cells of workers in banana farming.

\begin{tabular}{lrcc}
\hline Group & Pyknosis & Karyorrhexis & Karyolysis \\
\hline Controls $(\mathrm{n}=20)$ & $17.1 \pm 3.8$ & $2.0 \pm 1.7$ & $4.9 \pm 2.7$ \\
Workers $(\mathrm{n}=21)$ & $9.6 \pm 8.6$ & $61.3 \pm 49.7^{*}$ & $2.9 \pm 4.7$ \\
\hline
\end{tabular}

*Significantly different at $p<0.05$ when compared to controls.

Regarding cytotoxicity, the frequency of karyolysis in buccal mucosal cells was significantly increased in the experimental group when compared to the control group $(\sim 30$-fold, $p<0.05)$. Nevertheless, the frequency of pyknosis was not significantly altered in banana farm workers when compared to the control group. In the same way, no significant statistically difference $(p \geq 0.05)$ was found in the frequency of karrhyorexis. The numerical data are shown in Table II.

\section{Discussion}

The aim of this study was to evaluate chromosomal damage and cellular death in buccal mucosal cells from banana farm workers as indicators of genomic instability and cytotoxicity, respectively. To the best of our knowledge, this approach has not been taken so far.

The use of oral mucosaI cells has several advantages when compared to use of other cell types, such as lymphocytes, urothelial cells or in vitro cell cultures, since it is a noninvasive technique for collecting buccal cells and therefore is closely associated with the investigation of direct in vivo effects (19). In addition, the oral mucosa is one of the first sites when considering exposure to chemical agents, either through inhalation of the air or by the process of ingestion. It is noteworthy to consider that the majority of solid tumors originate from epithelial tissues, which would denote an increased risk for oral cancer, and also to other tissues of epithelial origin (20).

The detection of micronucleated cells in epithelial tissue is considered indicative of cancer risk since they 
represent chromosomal damage, as characterized by the initiation phase of carcinogenesis (21). Therefore, the presence of micronucleated cells in a target tissue is indicative of genomic instability (21). Our results demonstrated an increased frequency of micronuclei in buccal cells of workers in banana farming when compared to controls. Studies investigating the mutagenic potential of pesticides using the micronucleus test in buccal mucosaI cells are scarce in literature. An earlier study conducted by Benedetti et al. showed that pesticides were able to induce genotoxicity and mutagenicity in workers of soybeans as evaluated by comet and micronucleus assays, respectively. Such changes in the genome were associated with DNA hypermethylation (22). Other studies have also demonstrated such findings as increasing mutagenesis induced by the use of pesticides in agriculture $(23,24)$. Taken together, our results are consistent with the notion that banana farm workers continuously exposed to pesticides present genomic instability in buccal mucosal cells.

In order to better understand the mechanisms by which exposure to pesticides interferes with the biological machinery closely related to cell death, cytotoxicity was also evaluated in this setting. Among the parameters chosen for this purpose, pyknosis and karyolysis did not significantly differ between the two groups. However, a significant increase of karyorrhexis was detected in the buccal mucosal of banana farm workers. These results are in agreement with previous studies conducted by Benedeti et al. (25) and Kausar et al. (26), since they also identified an increase of meta-nuclear changes indicative of cytotoxicity in the oral mucosa of individuals exposed to pesticides. Nevertheless, others did not find any differences for this parameter of cell death in floriculturists (27). Overall, such findings suggest two important aspects that merit discussion: The first concern is due to the fact that pesticides appear to be capable of inducing cell death, as seems to be demonstrated by these results. The second finding is that karyolysis is closely associated with necrosis (28). Therefore, exposure to pesticides appears to be able to induce cellular death by necrosis. Taken as a whole, these data support the idea that the initiation-promotion process of carcinogenesis can be established in oral cells from banana farm workers, including individuals highly susceptible to chronic-degenerative diseases.

In conclusion, the results of the present study suggest that banana farm workers comprise a high-risk group for carcinogenesis, as revealed by micronucleus assay in buccal mucosal cells. This highlights the need to evaluate the sideeffects on health induced by occupational exposure to pesticides. Overall, these professionals should be examined regularly in order to prevent several diseases related to continuous chemical exposure.

\section{Conflicts of Interest}

The Authors declare that they have no conflict of interest in regard.

\section{Authors' Contributions}

JMMS, MCBA, LYY and DAR made the study design. SRC and ACRS analyzed all results. MCBA and DAR supervised the findings of this work. All Authors discussed the results and contributed to the final content of the manuscript.

\section{Acknowledgements}

DAR is a recipient of the Conselho Nacional de Desenvolvimento Cientifico e Tecnologico productivity fellowship.

\section{References}

1 UNESCO. Patrimônio Natural da Humanidade: Mata AtlânticaVale do Ribeira. 1999. Available at: <http://www.unesco.org/new/ pt/brasilia/culture/world-heritage/list-of-worldheritage $>$. Last accessed 1/14/2019.

2 FAO. Food and Agriculture Organization of the United Nations. Bananas. Available at: <http://www.fao.org/faostat/en/\#data/QC >. Last accessed 14/1/2019.

3 EMBRAPA. Empresa Brasileira de Pesquisa Agropecuária. Produção de bananas no Brasil. 2013. Available at: $<$ http://www.cnpmf.embrapa.br>. Last accessed 14/1/2019.

4 Barraza D, Jansen K, van Wendel de Joode B and Wesseling C: Pesticide use in banana and plantain production and risk perception among local actors in Talamanca, Costa Rica. Environ Res 111(5): 708-717, 2011. PMID: 21396636, DOI: 10.1016/j.envres.2011.02.009.

5 Wesseling C, Ahlbom A, Antich D, Rodriguez AC and Castro R: Cancer in banana plantation workers in Costa Rica. Int $\mathrm{J}$ Epidemiol 25(6): 1125-1131, 1996. PMID: 9027515.

6 Wesseling C, van Wendel de Joode B and Monge P: Pesticiderelated illness and injuries among banana workers in Costa Rica: A comparison between 1993 and 1996. Int J Occup Environ Health 7(2): 90-97, 2001. PMID: 11373051, DOI:10.1179/ 107735201800339506.

7 Vazquez Boucard C, Lee-Cruz L, Mercier L, Ramírez Orozco M, Serrano Pinto V, Anguiano G, Cazares L and Díaz D: A study of DNA damage in buccal cells of consumers of welland/or tap-water using the comet assay: Assessment of occupational exposure to genotoxicants. Environ Mol Mutagen 58(8): 619-627, 2017. PMID: 28714172, DOI: $10.1002 / \mathrm{em} .22111$.

8 Chiu YH, Afeiche MC, Gaskins AJ, Williams PL, Petrozza JC, Tanrikut C, Hauser R and Chavarro JE: Fruit and vegetable intake and their pesticide residues in relation to semen quality among men from a fertility clinic. Hum Reprod 30: 1342-1351, 2015. PMID: 25824023, DOI: 10.1093/humrep/dev064.

9 Dewailly E, Ayotte P, Bruneau S, Gingras S, Belles-lsles M and Roy R: Susceptibility to infections and immune status in Inuit infants exposed to organochlorines. Environ Health Perspect 108: 205-211, 2000. PMID: 10706525, DOI: 10.1289/ehp.001 08205 . 
10 Viel JF, Warembourg C, Le Maner-Idrissi G, Lacroix A, Limon G, Rouget F, Monfort C, Durand G, Cordier S and Chevrier C: Pyrethroid insecticide exposure and cognitive developmental disabilities in children: The PELAGIE mother-child cohort. Environ Int 82: 69-75, 2015. PMID: 26057254, DOI: 10.1016/ j.envint.2015.05.009.

11 Rugbjerg K, Harris MA, Shen H, Marion SA, Tsui JKC and Teschke K: Pesticide exposure and risk of Parkinson's disease A population-based case-control study evaluating the potential for recall bias. Scand J Work Environ Health 37: 427-436, 2001. PMID: 21240453, DOI: 10.5271/sjweh.3142.

12 Richardson JR, Shalat SL, Buckley B, Winnik B, O'Suilleabhain P, Diaz-Arrastia R, Reisch J and German DC: Elevated serum pesticide levels and risk for Alzheimer disease. Arch Neurol 66(7): 870-875, 2009. PMID: 19597089, DOI: 10.1001/ archneurol.2009.89.

13 Del Razo LM, Garcia-Vargas GG, Valenzuela OL, Hernandez Castellanos E, Sanchez-Pena LC, Currier JM, Drobna Z, Loomis $\mathrm{D}$ and Styblo M: Exposure to arsenic in drinking water is associated with increased prevalence of diabetes: A crosssectional study in the Zimapan and Lagunera regions in Mexico. Environ Health 10: 1-11, 2011. PMID: 21864395, DOI: 10.1186/ 1476-069X-10-73.

14 Provost D, Cantagrel A, Lebailly P, Jaffre A, Loyant V, Loiseau $\mathrm{H}$, Vital A, Brochard P and Baldi I: Brain tumours and exposure to pesticides: A case-control study in southwestern France. Occup Environ Med 64: 509-514, 2007. PMID:17537748, DOI: 10.1136/oem.2006.028100.

15 Beliën JA, Copper MP, Braakhuis BJ, Snow GB and Baak JP: Standardization of counting micronuclei: Definition of a protocol to measure genotoxic damage in human exfoliated cells. Carcinogenesis 16(10): 2395-2400, 1995. PMID: 7586141.

16 Tolbert PE, Shy CM and Allen JW: Micronuclei and other nuclear anomalies in buccal smears: Methods development. Mutat Res 271: 69-77, 1992. PMID: 1371831.

17 Souza AC, DA Silva VH, Seixas C, DE Oliveira Scudeller TT, DO Amaral MT and Ribeiro DA: Cytogenetic biomonitoring in buccal mucosa cells from women submitted to chemotherapy after mastectomy for breast cancer. Anticancer Res 36(4): 19551958, 2016. PMID: 27069186.

18 Pereira, CAB: Teste estatístico para comparar proporções em problemas de citogenética. In: Mutagênese, Teratogênese e Carcinogênese. Rabelo-Gay N, Rodrigues MA and MonteleoneNeto R (eds.) SBG, pp. 113-121, 1991 (in Portuguese).

19 Bonassi S, Coskun E, Ceppi M, Lando C, Bolognesi C, Burgaz S, Holland N, Kirsh-Volders M, Knasmueller S, Zeiger E,Carnesoltas D, Cavallo D, da Silva J, de Andrade VM, Demircigil GC, Odio AD, Donmez-Altuntas H, Gattas G, Giri A, Giri S,Gómez-Meda B, Gómez-Arroyo S, Hadjidekova V, Haveric A, Kamboj M, Kurteshi K, Martino-Roth MG, Montoya RM, Nersesyan A, Pastor-Benito S, Salvadori DMF, Shaposhnikova A, Stopper H, Thomas P, Torres-Bugarín O, Yadav AS, González GZ and Fenech M: The Human MicroNucleus project on eXfoLiated buccal cells (HUMNXL): The role of life-style, host factors, occupational exposures, health status, and assay protocol. Mutat Res 728: 8897, 2011. PMID: 21763453, DOI: 10.1016/j.mrrev.2011.06.005.
20 Holland N, Bolognesi C, Kirsch-Volders M, Bonassi S, Zeiger $\mathrm{Z}$, Knasmueller $\mathrm{S}$ and Fenech M: The micronucleus assay in human buccal cells as a tool for biomonitoring DNA damage: The HUMN project perspective on current status and knowledge gaps. Mutat Res 659: 93-108, 2008. PMID: 18514568, DOI: 10.1016/j.mrrev.2008.03.007.

21 Andrade MC, Dos Santos JN, Cury PR, Flygare AC, Claudio SR, Oshima CT and Ribeiro DA: Cytogenetic biomonitoring in buccal mucosal cells from municipal solid waste collectors. Anticancer Res 37(2): 849-852, 2017. PMID: 28179341, DOI: 10.21873/anticanres.11388.

22 Benedetti D, Lopes Alderete B, de Souza CT, Ferraz Dias J, Niekraszewicz L, Cappetta M, Martínez-López W and Da Silva J: DNA damage and epigenetic alteration in soybean farmers exposed to complex mixture of pesticides. Mutagenesis 33(1): 87-95, 2018. PMID: 29244183, DOI: 10.1093/mutage/gex035.

23 Tomiazzi JS, Judai MA, Nai GA, Pereira DR, Antunes PA and Favareto APA: Evaluation of genotoxic effects in Brazilian agricultural workers exposed to pesticides and cigarette smoke using machine-learning algorithms. Environ Sci Pollut Res Int 25(2): 1259-1269, 2018. PMID: 29086360, DOI: 10.1007/ s11356-017-0496-y.

24 Carbajal-López Y, Gómez-Arroyo S, Villalobos-Pietrini R, Calderón-Segura ME and Martínez-Arroyo A: Biomonitoring of agricultural workers exposed to pesticide mixtures in Guerrero state, Mexico, with comet assay and micronucleus test. Environ Sci Pollut Res Int 2016 23(3): 2513-2520, 2016. PMID: 26423288, DOI: 10.1007/s11356-015-5474-7.

25 Benedetti D, Nunes E, Sarmento M, Porto C, Dos Santos CE, Dias JF and da Silva J: Genetic damage in soybean workers exposed to pesticides: evaluation with the comet and buccal micronucleus cytome assays. Mutat Res 752(1-2): 28-33, 2013. PMID: 23347873, DOI: 10.1016/j.mrgentox.2013.01.001.

26 Kausar A, Giri S, Roy P and Giri A: Changes in buccal micronucleus cytome parameters associated with smokeless tobacco and pesticide exposure among female tea garden workers of Assam, India. Int J Hyg Environ Health 217(2-3): 169-175, 2014. PMID: 23706883, DOI: 10.1016/ j.ijheh.2013.04.007.

27 Wilhelm CM, Calsing AK, da Silva LB: Assessment of DNA damage in floriculturists in southern Brazil. Environ Sci Pollut Res Int 22(11): 8182-8189, 2015. PMID: 25516252, DOI: 10.1007/s11356-014-3959-4.

28 Cerqueira EM, Gomes-Filho IS, Trindade S, Lopes MA, Passos JS and Machado-Santelli GM: Genetic damage in exfoliated cells from oral mucosa of individuals exposed to X-rays during panoramic dental radiographies. Mutat Res 562(1-2): 111-117, 2004. PMID: 15279834, DOI: 10.1016/j.mrgentox.2004.05.008.

Received January 14, 2019

Revised January 30, 2019

Accepted February 4, 2019 